The Americas

63:3 January 2007, 359-383

Copyright by the Academy of American

Franciscan History

\title{
TRACES, IMAGES AND FICTIONS: PAUL STRAND IN MEXICO, 1932-34*
}

\begin{abstract}
7 his article analyzes an individual, a context, and an experience. The individual is the photographer and filmmaker Paul Strand, widely recognized and occasionally criticized as one of the great modernist photographers of the twentieth century. ${ }^{1}$ The context is Mexico from 193234. In these years, Strand worked in Mexico amidst state-led efforts to construct a "new" national culture following the social upheavals and military conflicts associated with the Mexican Revolution. ${ }^{2}$ The experience was Strand's effort to create a visual record of Mexico documenting what he thought of as its unique character, while furthering its "revolutionary" transformation through photography and filmmaking.
\end{abstract}

\footnotetext{
* The author wishes to acknowledge John Mraz as well as two anonymous reviewers for The Amer icas, whose comments greatly strengthened the final version of this article.

' For the political/cultural dimensions of Strand's move to Mexico as well as an analysis of his Mexican work, see John Mraz, "Ojos ajenos. Fotografías de extranjeros en México," unpublished paper. For the overall context of twentieth-century photography in Mexico, see also Mraz, "Photography in Mexico," in Encyclopedia of Twentieth-Century Photography, vol. 2, ed. Lynne Warren (New York: Routledge, 2006), pp 1033-1040; Mraz, Nacho López: Mexican Photographer (Minneapolis-London: University of Minnesota Press, 2003; Paul Strand: Essays on His Life and Work, ed. Maren Stange (New York: Aperture, 1990); Naomi Rosenblum, A World History of Photography, Third Edition (New York, London, Paris: Abbeville Press, 1997, orig. 1984), pp. 438-440; James Oles, South of the Border: Mexico in the American Imagination, 1914-1947 (Washington and London: Smithsonian Institution Press, 1993), p. 93; Horacio Fernández, "Paul Strand (y Anton Bruehl)," in Salvador Albiñana and Horacio Fernández, eds., Mexicana: Fotografía Moderna en México, 1923-1940 (IVAM Institut Valencià d'Art Modern, 1998), pp. 195-215; and Olivier Debroise, Mexican Suite: A History of Photography in Mexico, trans. Stella de Sá Rego (Austin: University of Texas Press, 2001, orig. 1994), pp. 5, 134-138.

2 Thomas Benjamin, La Revolución: Mexico's Great Revolution as Memory, Myth and History (Austin: University of Texas Press, 2000); Mary Kay Vaughan, Cultural Politics in Revolution: Teachers, Peasants and Schools in Mexico, 1930-1940 (Tucson: The University of Arizona Press, 1997), esp. pp. 25-46; David Craven, Art and Revolution in Latin America, 1910-1990 (New Haven and London: Yale University Press, 2002), pp. 25-73; Alexander S. Dawson, "From Models for the Nation to Model Citizens: Indigenismo and the 'Revindication' of the Mexican Indian, 1920-1940," Journal of Latin American Studies 30:2 (May, 1998), pp. 279-308; Guillermo Palacios, "Postrevolutionary Intellectuals, Rural Readings and the Shaping of the 'Peasant Problem' in Mexico: El Maestro Rural, 1932-1934, Journal of Latin American Studies 30:2 (May, 1998), pp. 309-339.
} 
Paul Strand's Mexican work consists of approximately one hundred and seventy five photographic negatives and sixty platinum prints, twenty of which Strand published in his 1940 Photographs of Mexico, re-released in 1967 as The Mexican Portfolio. ${ }^{3}$ While in Mexico Strand also played a major role in producing, photographing and directing the film Redes (1935), released with English subtitles as The Wave (1937). These efforts were well received in Mexico, at least in part because they conformed to the nationalist ethos of the 1930's. This was a significant achievement for a non-Spanish speaking norteamericano with limited knowledge of Mexico. Looking back in 1967, the great muralist David Alfaro Siquieros claimed that

Like Serge Eisenstein who preceded him, Strand made an outstanding contribution, notably with his film "Redes" (Nets), a work of dynamic realism, emotional intensity, and social outlook. It is a masterpiece, a classic of the Mexican, and by extension, of the Latin American milieu. This is equally true of the photographs that make up the Mexican Portfolio. ${ }^{4}$

Indeed, Siquieros considered Strand an "American-Mexican" who created "the most objective art of our time." The caricaturist, artist and archaeologist Miguel Covarrubias described Strand's Photographs of Mexico as "the finest job of reproduction of the finest photographs ever made of Mexico," and the advance sale subscription list for this volume contained many of Mexico City's intellectual and political elites. ${ }^{5}$

By the time Strand arrived in Mexico, he was an advocate of "straight photography," that is, photography prohibiting manipulation of the negative. ${ }^{6}$ Whether one accepts, qualifies or rejects modernist ideals of straight photography, it is necessary to recognize that all film images involve complex theoretical and practical issues at the levels of produc; tion, circulation and reception. These are reconfigured as technology changes, as for example with the introduction of cinema, or more recently

3 The figure of "approximately 175 " negatives was given in a personal communication with Anthony Montoya, Archivist, Paul Strand Archive. Naomi Rosenblum notes "60 images, printed in platinum." Naomi Rosenblum, "Strand/Mexico," in México Through Foreign Eyes/Visto por ojos extranjeros, ed. Carole Naggar and Fred Ritchin (New York and London: W.W. Norton \& Company, 1993), p. 27. Paul Strand's Photographs of Mexico (New York: Virginia Stevens, 1940) is quite rare. More readily available is Paul Strand, The Mexican Portfolio (New York: Da Capo Press, 1967).

${ }^{4}$ Paul Strand Archive, Aperture Foundation, Millerton, N.Y and Lakeville, Conn. The citations in this paragraph are from a microfiche copy of the Strand Archive of the Center for Creative Photography in Tucson, Arizona, listed as AG 17:1/1. "Publications: Mexican Portfolio, 1940."

5 Ibid.

6 A substantial defense of Strand's realism is Mike Weaver, "Dynamic Realist," in Stange, ed., Paul Strand, pp. 197-207. 
digital technology. ${ }^{7}$ A full exploration of these issues lies beyond the scope of this essay. However, Strand's ambivalent position as a norteamericano sympathetic to revolutionary nationalism, as well as his lifelong insistence on the objectivity of his art, makes his Mexican experience an intriguing place to begin a consideration of the links between individuals, contexts and images. ${ }^{8}$

Strand's trip to Mexico began in response to an invitation from his friend the composer Carlos Chávez, who had recently been appointed the director of the Fine Arts Department of the Secretariat of Public Education (SEP). For Strand as tourist, Mexico provided a temporary escape from a United States he perceived as increasingly restrictive in cultural and political terms. ${ }^{9}$ In this respect, his experience must be situated within an extended movement across international borders of people and cultures, a multi-directional flow of ideas and practices as well as labor, goods and services. ${ }^{10} \mathrm{On}$ a more personal note, Strand also fled the disappointments involved in the dissolution of a sixteen year relationship with his mentor Alfred Stieglitz, a divorce from his first wife and a failed Guggenheim Fellowship applica-

${ }^{7}$ An accessible guide is Terry Barrett, Criticizing Photographs: An Introduction to Understanding Images, 3rd ed. (Mayfield: Mountain View, California, Toronto, London, 2000), esp. pp. 96-139. Various lines of postmodernist critique include Roland Barthes, Camera Lucida: Reflections on Photography, trans. Richard Howard (New York: Hill and Wang, 1981), esp. p. 76. Susan Sontag, On Photography (New York: Farrar, Strauss and Giroux, 1977). See also Walter Benjamin's classic "The Work of Art in the Age of Mechanical Reproduction," in Illuminations, ed. Hannah Arendt (New York: Schocken Books, 1968), pp. 217-251. Eduardo Cadava, Words of Light: Theses on the Photography of History (Princeton: Princeton University Press, 1997). Vanessa R. Schwartz, "Walter Benjamin for Historians," American Historical Review 106, no. 5 (December, 2001), pp. 1721-1743. For a discussion of the impact of digital technology on photographic objectivity, see John Mraz, "What's documentary about photography?: From directed to digital photojournalism," http:/www.zonezero.com/magazine/articles/mraz/mraz01.html, parts $1-8$.

${ }^{8}$ On biography and images, see Nell Irvin Painter, "Ut Pictura Poesis; or The Sisterhood of the Verbal and Visual Arts" in Writing Biography: Historians and Their Craft (Nebraska: University of Nebraska Press, 2004), pp. 103-131; Fernando Coronil, "Seeing History," Hispanic American Historical Review 84:1 (February, 2004), pp. 1-4; William St. Clair, "The Biographer as Archaeologist," in Mapping Lives: The Uses of Biography, ed. Peter France and William St. Clair (Oxford and New York: Oxford University Press, 2002), pp. 219-234.

${ }^{9}$ Mraz, "Ojos ajenos."

10 Helen Delpar, The Enormous Vogue of Things Mexican: Cultural Relations Between the United States and Mexico, 1920-1935 (Tuscaloosa: University of Alabama Press, 1992); John Mason Hart, Empire and Revolution: The Americans in Mexico Since the Civil War (Berkeley, Los Angeles, London: University of California Press, 2002), pp. 367-399; Daniela Spenser, The Impossible Triangle: Mexico, Soviet Russia, and the United States in the 1920's (Durham and London: Duke University Press, 1999); Friedrich E. Schuler, Mexico Between Hitler and Roosevelt: Mexican Foreign Relations in the Age of Låzaro Cárdenas, 1934-40 (Albuquerque: University of New Mexico Press, 1998), pp. 33-62; Julio Moreno, Yankee Don't Go Home! Mexican Nationalism, American Business Culture, and the Shaping of Modern Mexico, 1920-1950 (Chapel Hill and London: The University of North Carolina Press, 2003), pp. 16-81. 
tion. ${ }^{11}$ In Mexico, Strand enjoyed a successful exhibition of his photographs in Mexico City and obtained work, originally at the level of elementary school art instructor and ultimately as the Director of Photography and Filmmaking for the Mexican Department of Fine Arts, a division of the Secretariat of Public Education (SEP). He would be forced to exit Mexico amid significant controversy in January $1935 .{ }^{12}$

The friendship between Carlos Chávez and Paul Strand apparently began in the 1920's. In 1976, as he prepared his comments for Strand's funeral service, Chávez recalled that they had "met in Taos," in the early 1930's, though earlier contact in the artistic circles of 1920's New York seems more likely. ${ }^{13}$ In 1923, Chávez traveled to New York, and he would return from 1926-1928. In addition to sharing an apartment with the artist Rufino Tamayo and supporting himself as an organist in a movie theater, Chávez developed a friendship with Aaron Copland that led to his music being performed to public acclaim. ${ }^{14} \mathrm{He}$ also developed his friendship with Paul Strand, though the historical record indicates that it was Strand's first wife Rebecca who took the time to write. On January 3, 1929 Rebecca congratulated Chávez on his 1929 appointment as director of the Mexican Symphony Orchestra, a position he would hold for several decades, writing, "I am glad the orchestra is a success-it was almost bound to be under your precise and eager leadership." On March 18, 1930 she wrote "Everybody has missed you very much in New York and the question always is "when is Carlos coming back"-Well, when are you coming back? She also indicated that "Paul and I have in mind to go to Mexico this summer-but it is still very unsure-one hears all sorts of tales from returned Americans about bad water, dysentery, poor food, etc.-but we would rely on your advice in that matter as you know what Americans are used to \& how they live."15

It is likely that Chávez and Strand built on an existing acquaintanceshiṕ during later visits to New Mexico. In August/September 1926 Strand trav-

\footnotetext{
11 Naomi Rosenblum, "Strand/Mexico," in México through Foreign Eyes/Visto por ojos extranjeros, 1850-1990, ed. Carole Naggar and Fred Ritchin (New York and London: Norton, 1993), pp. 27-40, p. 27 for invitation, divorce, Guggenheim denial. Katherine C. Ware, "Photographs of Mexico, 1940," in Paul Strand, ed. Stange, pp. 109-121, esp. p. 109 for break with Stieglitz, divorce, Guggenheim.

12 Rosenblum, "Strand/Mexico." Ware, "Photographs." Alan Trachtenburg, "Introduction," in Paul Strand, ed. Stange, pp. 1-17. Alexander William, "Paul Strand as Filmmaker, 1933-1942," in Paul Strand, ed. Stange, pp. 148-160. Calvin Tomkins, "Profile," in Paul Strand: Sixty Years of Photographs (Millerton, New York: Aperture, 1976), pp. 25-27. Jan-Christopher Horak, "Paul Strand: Romantic Modernist," in Making Images Move: Photographers and Avant-Garde Cinema (Washington and London: Smithsonian Institution Press, 1997), pp. 98-99.

${ }^{13}$ Carlos Chávez, "Paul Strand," draft. AGN Chávez Correspondencia Il Paul Strand.

14 Delpar, The Enormous Vogue, p. 44, pp. 86-87.

15 AGN Chávez Correspondencia II Rebecca Strand.
} 
eled to Estes Park and Mesa Verde, Colorado and Santa Fe and Taos, New Mexico. He would return to New Mexico in 1930, 31 and 32. ${ }^{16}$ On May 6, 1931, the Secretaría de Educación Pública (SEP) commissioned Chávez to study "the music of the Indian reservations in the United States." In the summer of 1931, Chávez enjoyed several dinners recorded in the society pages of New Mexico newspapers, which introduced him as a scholar and composer "studying the ancient music of the New Mexico pueblos through the summer." 17 Apparently, Chávez was well received. Several years later, in 1937 and re-married four years after her divorce from Paul Strand and permanent relocation to New Mexico, Rebecca would write "-Are you ever coming back to Taos?" She noted she would have to compete with Mabel Dodge Luhan for the chance to serve as his host should he choose to return. ${ }^{18}$

Up until this point, Strand's written communications with Chávez consisted of a brief telegram from Santa Fe, New Mexico on 16 November 1932.

Plan Driving in Car to Mexico City and Want Bring Along Examples My Work could you Get and Send Me Laredo General Delivery Some Official Letter Identification Perhaps From Saenz Facilitating Entry Photographs Into Mexico and Photographing While There Will Reach Laredo About Ten Days Thanks and Affectionate Greetings. Paul Strand ${ }^{19}$

MeXico, \#1: Photographs of MEXICO, 1932-1933.

Initially, one's eyes are drawn to the reed basket and the way that its interlocking pattern is set off from the interspersed, predominantly light and somewhat darker squares of the skirt, worn through in two places where small holes have emerged. The dark shawl interlaced with light tones is set off from the basket, the skirt and the weathered adobe wall, where the whitewash has begun to flake off, revealing the dark surface underneath. The shawl covers the arms, shoulder and head of a woman, revealing a striking face. In the end, however, it is the woman's eyes that provide the most startling detail, as the traits they hint at—strength, pensiveness, resolve, sadness-prove impossible to fix with certainty.

\footnotetext{
16 Steve Yates, "The Transition Years: New Mexico," in Paul Strand, ed. Stange, p. 87.

17 SEP, Departamento de Archivo Histórica y Reprografía, Colección Personal Sobresaliente, Expedients Personal, Chávez Ramírez, Carlos (SEP Chávez).

18 AGN Chávez Correspondencia II Rebecca Strand.

19 AGN Chávez Correspondencia II Paul Strand.
} 


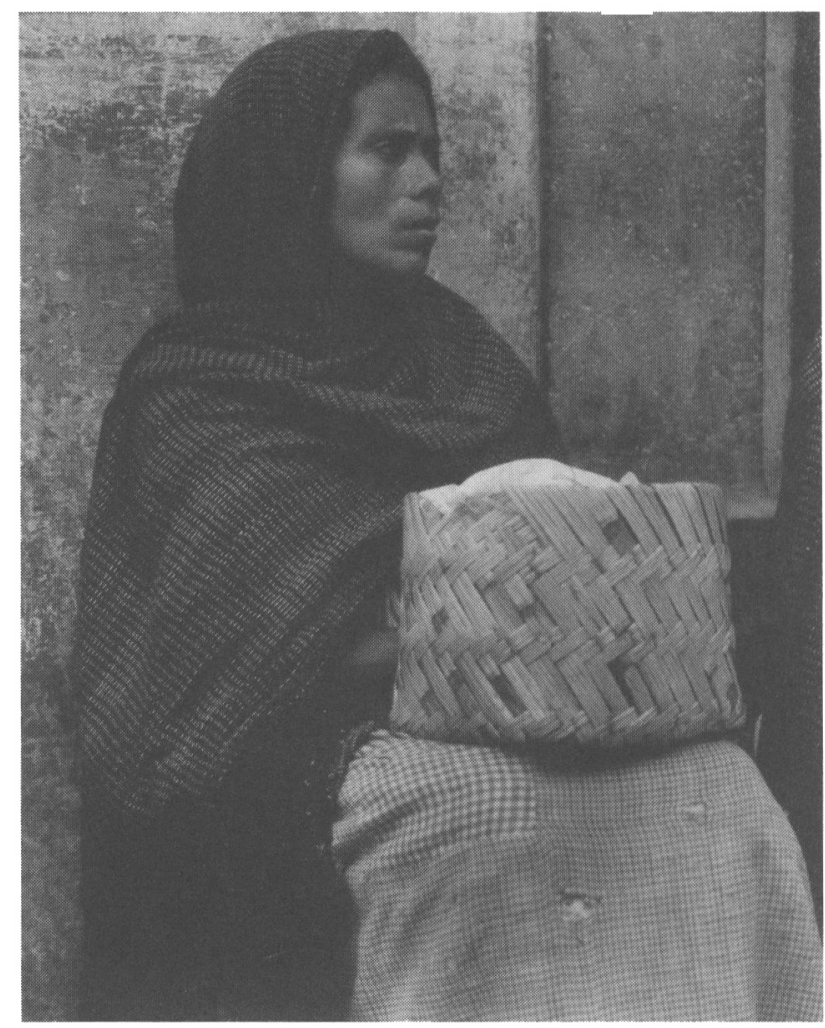

Paul Strand, Woman, Patzcuaro, Michoacan, Mexico, 1933

(C) Aperture Foundation, Inc., Paul Strand Archive

Paul Strand's Woman, Pátzcuaro, 1933 is an intrusive photograph, taken without the knowledge or consent of the person photographed. ${ }^{20}$ As Strand' himself recalled, "It turned out later that when I began to make portraits, especially in Mexico in 1933, that the Graflex was perfect with the attachment of a prism for photographing the people without their knowing that they were being photographed-which was absolutely essential because the Mexican Indians don't like being photographed." ${ }^{21}$ While future generations would be troubled by the ethical implications of such an approach, use of a hidden lens had been a common practice for several decades and was unquestioned in this era. For Strand, the issue was primarily a technical one. ${ }^{22}$ This quotation came in the context of a discussion of his 1931 switch

20 Oles, South of the Border, p. 95; Susan Sontag, On Photography, p. 14.

21 Strand, Sixty Years of Photographs, p. 153.

22 Mraz, "Envisioning Mexico," pp. 8-20. 
from a four-by-five hand held Graflex to a five-by-seven, which was so big it had to be put on a tripod, thus facilitating added accoutrements.

Strand had already used a prism lens in a series of individual portraits in New York in $1916 .{ }^{23} \mathrm{He}$ defended this approach for the New York portraits, stating "I always felt that my relationship to photography and people was serious, and that I was attempting to give something to the world and not exploit anyone in the process." ${ }^{24}$ Though this statement was sincere and undoubtedly true, it was also true that cultural distance and obvious power imbalances separated Strand from the subjects of his photographs in Mexico. In addition to a trick lens he needed a translator and a guide during his travels. ${ }^{25}$ The Mexican Secretaría de Educación Pública funded his efforts as part of an educational campaign aimed at shoring up the state's legitimacy. SEP considered this to be especially necessary in Michoacánwhere Strand took many of his photographs-at the time one of the most conflicted regions of Mexico. Indeed, Strand placed himself at considerable personal risk by traveling through former war zones passing through a still conflictual process of pacification. ${ }^{26}$

Thus, Woman, Pátzcuaro, 1933 was immersed in political conflicts, social networks of power and cultural ways of seeing at the time of its creation. These have become even more complex with the passage of time, as essentialist notions of lo mexicano or "Mexicanness" lost their relevance and the art market intervened with its related practices of collection and display. ${ }^{27}$ This photograph is an archetypal example of the gendered and racialized ethnographic other. Even so, it has a complexity lacking in more pedestrian images from the 1930 's. ${ }^{28}$ Although fitting within the category "archetype," it is also a social documentary photograph, depicting a real person engaged in an unscripted daily activity. It records one unique historical moment, situated in a specific context.

${ }^{23}$ Naomi Rosenblum, "The Early Years," in Paul Strand, ed. Stange, p. 41.

24 Ware, "Photographs," p. 119.

${ }^{25}$ Ware, "Photographs," pp. 111-112.

26 Vaughan, Cultural Politics; John Britton, Educación y radicalismo en México. I. Los años de Bassols (1931-34) (México, D.F.: Secretaría de Educación Pública, 1976); A brief overview of the social/political context of Michoacán in the 1930's can be found in James Krippner-Martínez, Rereading the Conquest: Power, Politics and the History of Early Colonial Michoacán, 1521-1.565 (University Park, Pennsylvania: Pennsylvania State University Press, 2001), pp. 170-179.

${ }^{27}$ On "lo mexicano," see The Mexico Reader: History, Culture, Politics, ed. Gilbert M. Joseph and Timothy J. Henderson (Durham and London: Duke University Press, 2002), pp. 9-54. Roger Bartra, The Cage of Melancholy: Identity and Metamorphosis in the Mexican Character, trans. Christopher J. Hall (New Brunswick: Rutgers University Press, 1992, orig. 1989).

28 Adriana Zavala, "Constituting the Indian/Female Body in Mexican Painting, Cinema and Visual Culture, 1900-1950" (Ph.D. diss., Brown University, 2001), pp. 109-150. 
From 1931-1934, Narcisso Bassols served as director of the Secretaría de Educación Pública (SEP). Described as "the first Marxist to reach a position of importance in the Mexican government," Bassols presided over a tumultuous three years marked by conflicts over the secularization of education, sexual education, and struggles within SEP between teacher's unions and the SEP administration based in Mexico City. ${ }^{29}$ Carlos Chávez played a key role in the Bassols administration at SEP, first as a composer and conductor and then after March 1933 as head of the Fine Arts Department. ${ }^{30}$ Strand's friendship with Chávez was of critical importance throughout his time in Mexico, providing him entry into the country and financial support that allowed him to extend his visit. As we shall see, by the end of 1934 the shifting fortunes of Bassols and Chávez also resulted in the end of Strand's Mexican experience.

Strand recalled his first days in Mexico during an interview towards the end of his life.

I went to Mexico in the late fall of 1932 having already written to Carlos Chávez. At that time he was head of the Conservatory of Music and leader of the orchestra. I had written to him saying that I would like to come to Mexico and did he think he could do anything about smoothing the way as far as customs was concerned with all the camera equipment and so on. I got a kind of official invitation through him that was very helpful at the border. And with two friends of mine-Susan Ramsdell, who is an Indianologist, and her eighteen-year old son-she was a Texan, and a very fine person whom we had met the first time we went to Taos-the three of us set off in an old Model A Ford to drive to Mexico City. ${ }^{31}$

He seemed somewhat uneasy in his unfamiliar surroundings, though he began photographing immediately.

I started working in Mexico the minute I crossed the border. It was a continuation of New Mexico although quite different. Even the mountains are different. They're supposed to be a part of the same mountains, but they don't look the same. And they don't have the same kind of character. They have a different feeling, more sinister than the Rocky Mountains. ${ }^{32}$

It is not possible to determine Strand's precise trajectory from Santa Fe to Laredo, or from Laredo through the "sinister" mountains of northern Mexico,

${ }^{29}$ John A. Britton, Educación y radicalismo en México. I. Loa años de Bassols (1931-34) (México,

D.F.: Secretaría de Educación Pública, 1976), p. 12.

${ }^{30}$ Delpar, The Enormous Vogue, p. 89.

31 Strand, Sixty Years, p. 155.

32 Ibid. 
to Mexico City. Nor do we know the date when he and his traveling companions parted company. Nevertheless, it was a hard trip. By early 1933 when they arrived in Mexico City "the whole back of the car was broken." ${ }^{33}$

From February 3-15, 1933, a public exhibition of Strand's photographs was held in the Sala de Arte of the Palacio de Bellas Artes. ${ }^{34}$ As Strand explained in a letter to Stieglitz, "When I came to Mexico I brought fifty four prints along including last summers work, with no idea of a public exhibition-anything but. However, when Chávez saw the things he felt Mexico should have the opportunity to see (photography) ... how were they greatly impressed, for these people are very quick and intelligent." Strand also dis'cussed the difficulties of hanging the pictures and arranging the lighting, though he noted that the experience he had gained in Stieglitz's galleries proved invaluable. ${ }^{35}$ The support of Bassols had been critical as well. As Strand recalled: "We showed the photographs to Bassols and he said "yes."

Almost all the photographs Strand displayed were from 1930-32. They consisted primarily of selections from New Mexico, as well as Colorado, Maine and Canada. He also displayed seven portraits of Rebecca Strand and three of the Irish poetess Ella Young. ${ }^{37}$ For Strand, the exhibit was exhilarating. On October 14, 1933 he wrote to Ansel Adams "The best part of it was the democratic character of the people who came [. . . S Some 3000 in 10 days. . . I have worked here-started new problems - and have taken up a line of work started way back in 1915." ${ }^{38}$ As late as 1974, Strand still reminisced about his Mexican exhibition fondly, recalling that

With the show at street level, people would go in one door, go through the room, and out the other door. It became part of the street. All sorts of people came: policeman, soldiers, Indian women with their babies, and so on. I've never had such an audience anywhere else. ${ }^{39}$

His acceptance in Mexico encouraged Strand to stay, and thus the "ongoing work" he referred to in the letter to Adams continued over the next sev-

33 Ibid.

${ }^{34}$ SEP, Memoria relativo al estado que guarda el ramo de educación publica, tomo 1, Exposición (México, D.F.: Talleres Gráficos de la Nación, 1933), p. 417; Debroise, Mexican Suite, p. 134.

${ }^{35}$ As cited in Steve Yates, The Transition Years: Paul Strand in New Mexico (Santa Fe: Museum of New Mexico, 1989), p. 42.

36 Strand, Sixty Years, p. 155.

37 Albiñana, Mexicana, p. 198.

38 Yates, The Transition Years, p. 42. I have slightly edited the quotation as found in Yates, though all of Strand's words remain.

39 As quoted in Ware, "Photographs," p. 112. 
eral months. For Strand to finance an extended visit, however, he needed to find work,

Reading back through the SEP archives allows an employment timeline to emerge, though it also demonstrates how paper trails only loosely conform to actual practices. We know from his photographs and film that Strand traveled throughout the states of Michoacán, Hidalgo, Puebla, México, Oaxaca, Veracruz and possibly Tlaxcala. ${ }^{40}$ His collaboration with Augustin Velázquez Chávez-the young nephew of Carlos Chávez and an art teacher working in Michoacán, who served as Strand's translator and guidegreatly enhanced the experience. On May 24, 1933, Strand and Velázquez Chávez worked together on an exhibition of children's art from SEP sponsored art schools in Michoacán. ${ }^{41}$ It is possible that Strand spent May 1933 working in Mexico City, met Velázquez Chávez around the time of this children's art exhibit, and then went with him to Michoacán, where he took many of his Mexican photographs before journeying on to other states. Or, perhaps they worked on the children's art exhibit and when it was completed headed off for a working summer vacation.

Strand's paid employment in Mexico began on May 1, 1933. A SEP memorandum of May 3 noted Strand had obtained work at the level of elementary school art teacher requiring twelve hours weekly in the classroom for a salary of $\$ 82.12$ pesos monthly. Strand would sign a more formal agreement accepting this position on May 6. On June 9, 1933 Strand would be given permission to spend 10 days in Uruapan, and on June 13 he would be given permission to continue his work in Uruapan, Michoacán for 21 days without losing his position in Mexico City. These permissions were both retroactive to June 1. On July 3 Strand's position as an elementary school art teacher was officially renewed in a document signed by Carlos Chávez. On July 10, his permission to stay in Michoacán was lengthened for ten more days dating from the past June $22{ }^{42}$ These retroactive permissions probably were necessary for Strand to receive a SEP paycheck while pursuing his photographic work.

It is not entirely clear how much time Strand spent teaching elementary school art, though perhaps he did so. Given that the exhibit of children's artwork from the art schools of Michoacán was held on May 24, it is plausible to suggest that Strand worked with Velázquez Chávez on this event, and then

40 Ware, "Photographs," pp. 111-112.

41 Ware, "Photographs," pp. 112-113.

42 SEP, Departamento Administrativo, Año de 1933, Referencia I-/131\%. Expediente 41402. Legajo 1. Strand, Paul. 
set off to photograph in Michoacán during June before traveling to the other states in July and August. Carlos Chávez had taken Leopold Stokowski, director of the Philadelphia symphony, on a similar tour of Oaxaca and Michoacán in $1931 .^{43}$ Perhaps his new administrative responsibilities as director of Bellas Artes required Carlos Chávez to turn Strand over to his nephew. As Strand's translator and guide Velázquez Chávez played a critical role in the making of the photographs during 1933, all save one of those that appear in Strand's Photographs of Mexico. As we shall see, Velázquez Chávez also played a more conflictive role in the making of the movie Redes.

Photographs of Mexico is distinguished by the selecting and ordering of the twenty images it contains, including one landscape; three primarily architectural photos with an emphasis on gateways, doors and windows; five examples of religious sculpture, including one Virgin and four Christs in various stages of torment and crucifixion; and eleven biographical portraits, depicting men, women and children individually and together, as well as women with children. ${ }^{44}$ Each photograph refers to and introduces the next, which in some way enhances the previous image. For example, Near Saltillo, the first image and the only one dating from 1932, provides a sense for the physical environment of northern Mexico, as seen by Strand after entering the country and driving south towards Mexico City. Although primarily a landscape, it contains faint evidence of human activity and the built world in the shape of the distant, tiny doorway of an adobe structure far behind the cactus, brush and trees in the foreground of the picture. The next image includes more architectural detail by providing a closer look at an arched gateway framing the open doors and second floor window of a centuries old church. The delicate facial features and intricate decoration of a cane paste Virgin are next. The posture, expression and clothing of the Virgin have at least a surface resemblance to those of the indigenous women in photograph number four, Women of Santa Anna, despite the fact that the sculpture was from Oaxaca, while the women were from Michoacán. Architectural details including a doorway and a wall frame the group of women from Santa Anna. Photograph number five, The Men of Santa Anna, also contains the architectural details of a wall and doorway as well as two men in campesino dress. Their guarded and frankly hostile expressions demonstrate the utility if not the ethics of the trick lens. The next photograph, Woman, Pátzcuaro has been described. It is followed by Boy, Uruapan, an obviously posed individual portrait of a child that also includes traditional dress and architectural detail. The remaining ten photographs intersperse

43 Delpar, The Enormous Vogue, p. 88.

44 The images are reproduced in Albiñana, Mexicana, pp. 212-214. 
biographical portraits with religious sculpture and architecture in an attempt to provide a comprehensive portrait of Mexico.

Photographs of Mexico was a decisive break with Strand's earlier work that set the parameters for the rest of his career. ${ }^{45}$ In Mexico, for the first time, Strand sought to create a visual social history through photography, a pattern he would later follow in New England, France, Italy, the Outer Hebrides Islands, Egypt, Romania, Morocco and Ghana ${ }^{46}$ The obvious omissions of urban Mexico, evidence of applied science such as industry and advanced technology, many indigenous and all non-indigenous contexts, as well as the degradations of poverty and ostentations of wealth, demonstrate the limits to his vision ${ }^{47}$ Nevertheless, he provides complex and at times stunning visual representations of those aspects of Mexico he chose to photograph.

Strand's images of religious sculpture and especially the suffering Christ are perhaps the most striking, especially because they appear to emerge out of and blend into the postures, faces and clothing of his biographical portraits. This apparent sympathy for the religiosity of the rural poor challenged some of Strand's acquaintances back in Mexico City, due to the centrality of Church-State conflict in the Mexican Revolution. However, according to Naomi Rosenblum, "For him, the religious figures he photographed symbolized this 'intense faith' which he felt the world badly needed, although in different, more 'realistic' form." ${ }^{\prime 48}$

Strand's time in Mexico occurred just after an extraordinarily intense period of cultural conflict, in fact a civil war pitting the revolutionary state against a devoutly Catholic peasantry that cost Mexico approximately 80,000 lives. ${ }^{49}$ This conflict was especially fierce and had not entirely sub-

45 A similar break occurred in Mexico for Edward Weston, whose visit to Mexico and well known liaison with Tina Modotti preceded Strand by almost a decade. See Amy Conger, Edward Weston in Mexico, 1923-26 (Albuquerque: University of New Mexico Press, 1983); Sarah M. Lowe, Tina Modotti and Edward Weston: The Mexico Years (London and New York: Merrel, 2004). A burgeoning literature on Tina Modotti has developed as Modotti's photographs have become increasingly prominent and commercially valuable in the world of the fine arts. Selected recent works from a much more extensive bibliography include Andrea Noble, Tina Modotti: Image, Texture, and Photography (Albuquerque: University of New Mexico, 2000); Patricia Albers, Shadows, Fire, Snow: The Life of Tina Modotti (New York: Clarkson Potter, 1999).

${ }^{46}$ Albiñana, Mexicana., pp. 209-210. Ware, "Photographs," p. 110. Stange, ed., Paul Strand, pp. 263-267.

${ }^{47}$ Caroline Naggar, "The Fascination For the Other," in Mexico Through Foreign Eyes, ed. Naggar and Ritchin, p. 47.

48 Rosenblum, "Strand/Mexico," p. 27.

${ }^{49}$ Recent work includes Jennie Purnell, Popular Movements and State Formation in Revolutionary Mexico: The Agraristas and Cristeros of Michoacán (Durham, N.C.: Duke Universitv Press, 1999), 
sided in Michoacán as Strand was taking his photographs. In addition, Strand's employers at SEP harbored deeply anti-clerical sentiments. ${ }^{50}$ In this context, his insistence on documenting the religiosity of poor rural people in a dignified way is arguably the most striking aspect of Strand's Photographs of Mexico.

\section{MeXICO, \#2: The FiLMING OF REDES}

... In a world in which human exploitation is so general it seems to me a further exploitation of people, however picturesque, different and interesting to us they may appear, to merely make use of them as material.

—Paul Strand, $1936^{51}$

On September 25, 1933, Agustin Velázquez Chávez "remained commissioned with Mr. Paul Strand" to pursue the work of filmmaking. ${ }^{52}$ Strand did not resign his teaching position until December 15, 1933, with wages paid until December 26. On January 10, 1934, Strand signed a new contract to serve as Director of the Office of Photography and Cinema, retroactive to January 1, utilizing the trademark green ink that would become well known to collectors of fine photography in the years to come. ${ }^{53} \mathrm{He}$ would spend January through December 1934 on site in Alvarado, Veracruz making Redes. ${ }^{54}$ The resulting film is generally considered a classic in the history of Mexican cinema. It also places Strand within a tradition of foreign filmmakers working in Mexico. Though a distinctive work, Redes with its contradictory blend of socialist realism and romantic modernism is comparable to Eisenstein's unfortunate ¡Que Viva México!, as well as John Steinbeck's more successful The Forgotten Village. ${ }^{55}$

Initially, Carlos Chávez hired Strand to make a series of films over five years as part of a larger educational and visual effort promoted by the SEP. ${ }^{56}$

pp. 48-196; Marjorie Becker, Setting the Virgin on Fire: Lázaro Cárdenas, Michoacán Peasants and the Redemption of the Mexican Revolution (Berkeley, Calif.: University of California Press, 1995), pp. 6, 40, 125; Christopher R. Boyer, Becoming Campesinos: Politics, Identity, and Agrarian Struggle in Postrevolutionary Michoacán, 1920-1935 (Stanford, California: Stanford University Press, 2003), pp. 154-187.

50 Vaughan, Cultural Politics, pp. 29-33. Britton, Educación, pp. 23-116.

51 Robert Stebbins, "Redes," New Theatre, November 1936. In AGN Chávez Escritos 2 Redes 1937-38.

52 SEP, Año de 1933, Referencia D/1317 Expediente 41535, Velazquez Chávez, Agustin.

53 SEP Strand.

54 Albiñana, Mexicana, p. 198.

55 See Inga Karetnikova, Mexico According to Eisenstein (Albuquerque: University of New Mexico Press, 1991); Joseph Millichap, Steinbeck and Film (New York: Ungar, 1983).

56 Tomkins, "Profile," 26. SEP, Memoria, 1932, pp. 491-496. Ibid., 1933, p. 419. Ibid., 1934, pp. $340-41$ 


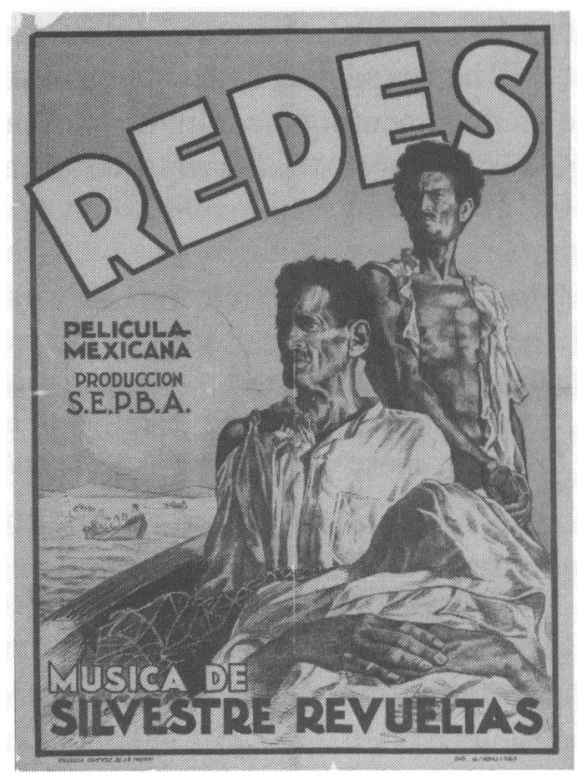

Poster Promoting Redes/The Wave, ca. 1937. Paul Strand Collection. Center for Creative Photography, University of Arizona.

Given the strong current of nationalism associated with the Mexican Revolution, hiring Strand for this position had to be justified. Thus, his employment required that he work with Mexicans in a collective effort to master the techniques and technology of filmmaking, a task he readily accepted. ${ }^{57}$ The enthusiasm of the moment, when a relatively new technology held out a utopian possibility for transforming consciousness, can be lost when we look back from a distance of more than seventy years. Today, the "Plan para la filmación de peliculas educativas" seems narrowly didactic and rigidly, ideological. ${ }^{58}$ The series of SEP films that Strand originally agreed to develop were required to "show in an objective way the production of wealth within the current social regime" so as "to create social and socioeconomic consciousness." To do so, all films would unfold in a sequence that passed in a linear way from "phenomena of the physical and biochemical sciences to those of the economic and social sciences, properly stated." A seven point plan required the films to move through stages discussing natural resources and the ability of "man" to usefully employ them through

\footnotetext{
57 "Strand and Chávez to Ignacio Garcia Telles," February 28, 1935. AGN Chávez, Caja Correspondencia II "Paul Strand 1930-39."

${ }^{58}$ The precise authorship of this document, which has a "boilerplate" quality, is difficult to determine. It summarizes the ideological ambience of SEP at this time, a milieu that Chávez and Strand supported and helped define.
} 
muscular and intellectual ability; the distinct regions of the country and the need for transport, commerce and warehousing; the emergence of a class that dominates industry and commerce; the rise of a working class and unions; and the emergence of a complex social order, including the "extreme types" of "day laborers and the great bourgeoisie," but also "many other classes with or against the bourgeoisie," depending on circumstances. In the end, the films were "to demonstrate in an objective manner the possibility of a social regimen whose justice is rooted in all men working and all equally obtaining the satisfaction of their needs." 59

The making of the film Redes was as utopian a socialist project as one could imagine in the early 1930 's. ${ }^{60}$ It was to be a collaborative effort, involving Paul Strand, some of his acquaintances from the United States, several Mexican nationals and the local population of Alvarado. Produced on a minuscule budget, the film was to show the struggles of the fishermen of Veracruz as they battled unjust economic and social forces, ultimately discovering that unionization was the only way to improve their situation. The story revolved around the hero Miro, a young fisherman who becomes a martyr to the cause. Miro was played by Silvio Hernandez, at that time a college student from Mexico City and one of only two professional actors in the film. The other was the "acaparador" or monopolistic fish buyer, who along with his underling the local politician was the major bad guy of the film. By using amateur actors in real life situations as much as possible, the filmmakers hoped to enhance the realism and didactic purpose of the film. The need to contain costs also figured into this aspect. The film was a low budget production and SEP administered the funding from Mexico City, releasing it every few weeks as Strand submitted old receipts and new budget requests. Strand even planned to sell the nets and boats purchased to make the film after they had finished, as well as the production crews' share of the fish caught, to help cover expenses. ${ }^{61}$

Those from the United States who worked on the film in Alvarado included Paul Strand, Fred Zinnemann, Henwar Rodakiewicz, Ned Scott

\footnotetext{
59 "Plan para la filmación de peliculas educativas." AGN Chávez INBA Vol. II, Caja 2 "Filmación Peliculas."

${ }^{60}$ As such, this effort paralleled liberal/leftist tendencies of the same era in Hollywood. Though Strand never worked in Hollywood, several of his colleagues from Redes would. Only one of the crewmembers, Fred Zinnemann, was already established in Hollywood at the time of the making of Redes. For the general ambience of the era in Hollywood, see Nancy Lynn Schwartz, The Hollywood Writers Wars (New York: Knopf, 1982); David F. Prindle, The Politics of Glamour: Ideology and Democracy in the Screen Actor's Guild (Madison: University of Wisconsin, 1988); Ron Brownstein, The Power and the Glitter (New York: Pantheon, 1992).

61 "Strand to Chávez," Januäry 27, 1934. AGN Chávez, Sección Orquesta Sinfónica de México, INBA 2, Vol. II, Caja 2. "Paul Strand: Correspondencia."
} 
and Barbara Messler (whom Strand noted worked at her own expense as a secretary and on the script). Guenther Von Fritsch would help edit the film in Mexico City, and John Dos Passos and Leo Hurwitz would later provide English sub-titles. Mexicans involved in writing the script and producing the film included Julio Bracho, Emilio Gomez Muriel, and Augustin Velázquez Chávez. Even prior to arriving in Alvarado, Strand worked with Carlos Chávez and Augustin Velázquez Chávez elaborating various drafts of the script. According to Strand, the original idea for the movie had occurred to him after he and Velazquez Chávez had made a "short visit" to Alvarado. ${ }^{62}$ Strand later commented "The script really meant a great deal to me since it grew out of my contact with Mexico and my feeling about life in general." 63 A political change also grew out of his contact with Mexico, where the revolution's multiple tendencies and varied trajectories shifted to the left in the 1930 's. ${ }^{64}$ According to Fred Zinnemann, when he arrived in Veracruz he found Strand to be "the most doctrinaire Marxist I had ever met." 65 Though his increasing socially awareness began in the 1920's, Strand became a Marxist in Mexico, and he remained a Marxist for the rest of his life. As he put it in a 1933 letter to his close friend and confidant Kurt Baasch "I don't know whether I can be labeled a Communist but I find the ideas of Marx which I have been reading very true to me-an ideal to be sure far distant even in Russia-but the only one left, that has hope in it for a decent human life." ${ }^{66}$ This recent conversion explains the coherent story line found in Redes. It is less useful, however, in helping us muddle through the conflicts, detours, and abuses found in the shadowy spaces behind the scenes.

One can only imagine the full impact of the arrival of a filmmaking crew in what at the time was a relatively small fishing village on Mexico's Caribbean coast. Despite the ideological clarity of SEP's instructions, the realities of life and the actual practice of making a film under existing con-r straints soon challenged everyone's understandings. In fact, the friendly, "off-the-record" sequence of letters sent by Strand in Alvarado to Chávez in Mexico City reveal that the making of the film Redes was a far more con-

\footnotetext{
62 "Strand and Chávez to Ignacio Garcia Telles," February 28, 1935. AGN Chávez, Caja Correspondencia II, Paul Strand, 1930-39.

63 Strand, Sixty Years of Photographs, p. 157.

${ }^{64}$ For an extraordinarily thorough guide to these shifts and varied receptions among diverse constituencies in the United States, as well as in the expatriate US community in Mexico, see John A. Britton, Revolution and Ideology: Images of the Mexican Revolution in the United States (Lexington: The University Press of Kentucky, 1995), esp. pp. 116-158.

65 Weaver, "Dynamic Realist," p. 199.

66 "Strand to Kurt and Isabel Baasch," Nov. 23, 1933. Center For Creative Photography, AG 137 Kurt Baasch Collection.
} 
tentious, unplanned, and difficult process than one might expect from a utopian experiment in collaborative filmmaking. ${ }^{67}$ Very early in the process it became clear that Strand's desire for an epic film that would surpass the work of Eisenstein did not mesh with SEP's plan for relatively straightforward educational documentaries. Problems with cost overruns and production delays plagued the film from the start.

On January 27,1934 , Strand wrote that they hoped to pay the fisherman $\$ 1.50$ a day, the prevailing minimum wage, and to get done before the end of February and the start of the fishing season. However, they were running into "costly delays that endanger the film." The crew had obtained a house-- "four 'rooms-second story with a balcony looking out over the lagoon-very grandquiet and private." Unfortunately, that was all that they were able to do because "we are for the moment out of funds." Strand wanted a bank account established in Veracruz because "These fisherman are poor people and must be paid daily." As he stressed to Chávez, the fishermen liked to fish, and if they weren't paid immediately they didn't like to watch others fishing while they pretended to fish. Julio Bracho, one of the Mexicans hired to work with Strand, had missed the morning train though he was expected to arrive soon. Apologetically, Strand confided to Chávez "I hate to bother you about these things that go wrong-you have enough on your minds-But I have the feeling that there is no one else who gives a damn. ${ }^{.68}$ All of Strand's letters to Chávez are in English, and his lack of ability to communicate in Spanish must have led to significant misunderstandings on the local level.

Some of the residents of Alvarado saw their opportunity. On February 9, Strand wrote complaining that "Some fellows had a net, in poor condition and tried to get a big price from us-the only way out of that was for me to become a 'fish buyer' but not an 'acaparador'. Antonio, as usual to the rescue." Antonio Lara was an elderly fellow who would play one of the most memorable roles in the film, when in a moment of desperation he tries to slash the fishing nets with a knife. According to Strand, the filmmakers where very dependent on Antonio, as "he is a jewel of a man-terribly important to us." Antonio hired the men for the film, pointing out who was honest and reliable and who was not. Initially, his home address was also where Strand received communications from Chávez. ${ }^{69}$

\footnotetext{
${ }^{67}$ Though perhaps not. As John Mraz points out, "Any filmmaker knows it won't be what you expected." Mraz, personal communication, 5/12/06.

68 "Strand to Chávez," January 27, 1934. AGN Chávez Paul Strand, 1930-39.

69 "Telegram from Chávez to Sr. Paul Strand." SEP, Departamento de Archivo Historico, Fondo S.E.P., 1931-35, Sección de Bellas Artes, Serie Cinematografía (SEP Cinematografía).
} 
In the end, Strand brought a boat and net for $\$ 800$ pesos and began to shoot the film. Strand complained about delays in seeing the results, since the film had to be shipped to Hollywood, where it would be developed in the Roy Davidge laboratories and then shipped back. There were also problems with the cameras, film, sand and salt air. On February 21, Strand requested an additional lens. With some desperation, he also indicated that the first consignment of film shipped to Hollywood had disappeared: "I hope whatever can be done in Mexico to trace the box, is being done. It is a hellish business, but I am determined to straighten it out, and to get the film moving in both directions without stoppage." However, on a positive note he commented "Yesterday we continued shooting the funeral sequence with our crew, 40 extras, and 35 school boys, quite a crowd." 70

One of the more colorful letters housed in the Chávez collection is from Frank X. Moore of El Paso, Texas. Moore's stationary describes him as a "Custom Broker Purchasing Agent, Receiving and Forwarding Agent and Drawback Specialist." Moore apparently specialized in finding things lost in Mexico. Fred Zinnemann recommended him to Strand as someone who could retrieve the missing film, as Hollywood movie companies frequently employed him in this capacity. On February 20th, Strand received a long letter from Moore.

Dear Mr. Strand:-my wire to you of the 19th has no doubt been received long ago and I trust that by this time you have raised plenty of hell and that by so doing will eliminate much future trouble. It was necessary for me to spend much time and I tried for two days straight to get a definite answer from the Customs Agent in Juarez and then had to tell them that if the film was not crossed at once I was going to take it upon myself personally to see that every damned one of them got fired. It sure is hell to get any action out of these birds and of all fool things to hold a shipment for-is for the crossing charges and handing charges by the National Lines office. ${ }^{71}$

Moore went on to provide a very detailed history of Strand's film along with a plan for avoiding future problems that involved a deposit of funds and finding a "big shot" in Mexico to put pressure on Mexican customs agents. ${ }^{72}$ Customs problems also slowed the return of the developed film from the United States side of the border. ${ }^{73}$ By February 26, Strand could only complain: 'In Hollywood they see the 'rushes' the next morning, so you see

70 "Strand to Chavez, "February 9 and February 21, 1934. AGN Chávez Paul Strand 1930-39.

71 "Moore to Strand," February 20, 1934. AGN Chávez, INBA Vol. II, Caja 2, Filmación Peliculas.

72 Ibid.

73 “Thomas D. Bowman to Alfonso Cortina," July 2, 1934. SEP Cinematografía. 
what saintliness is demanded of us-what patience. When I finish this film I expect to have acquired a magnificent shining halo-that glows even in the daytime - and is very pretty." ${ }^{74}$ At the end of March, after yet another request for funds to restart stalled production, Chávez could only write to Strand "creative genius consists precisely in making things of the highest importance out of nothing." 75

In addition to technical and budgetary issues, problems developed among the filmmakers, as well as between the filmmakers and the local population. ${ }^{76}$ Augustin Velazquez Chávez returned to Mexico City shortly after arriving in Alvarado, in late December 1933, apparently for health reasons 'though Strand would later claim that he lost his desire to learn cinematography. ${ }^{77}$ SEP records indicate that by April he was teaching in Mexico City. ${ }^{78}$ Julio Bracho, the other young Mexican that Strand was supposed to train, never seemed to have much enthusiasm for the project. By March 12, it was clear that personal problems had developed. Strand wrote that Bracho had returned late to filming and then had left unexpectedly. Strand was worried about the implications of one of the Mexican nationals quitting. He wrote "I feel it should be clear to people like Herzog that Bracho is taking himself out of the work-and that we made every effort to include and give experience to a Mexican-I regret the whole thing. I like Bracho as a person. Still do-."79 On March 16, Carlos Chávez wrote to Strand that he had spoken with Bracho who had decided that he wanted to work in Mexico City. Chávez told Strand that Bracho would be replaced by Emilio Gómez Muriel, "whose opinion ought to be taken very much into account in those questions related to genuinely national or local expressions of the film as much in the scenes themselves as in the dialogue." ${ }^{80}$ Strand wrote favorably about Gómez Muriel's work, despite his relative youth, and in fact Gómez Muriel would go on to enjoy a successful career in the Mexican film industry. At this distance, it is impossible to say whether Strand was a tyrant, or the younger Mexican filmmakers were immature or simply preferred Mexico City, or all of the above. However, these incidents reveal that tensions existed among

74 Strand to Chávez, February 26, 1934. AGN Chávez Paul Strand: Correspondencia.

75 "Chávez to Strand," March 22, 1934. AGN Chávez Paul Strand: Correspondencia.

76 The gap between the filmmakers and the local population points towards a larger tension, sometimes successfully negotiated though frequently not, within the cultural project of the revolution. See Alan Knight, "Popular Culture and the Revolutionary State in Mexico, 1910-1940," Hispanic American Historical Review 74:3 (Aug., 1994), pp. 393-444.

77 "Strand and Chávez to Ignacio Garcia Telles," February 28, 1935. AGN Chávez Paul Strand: Correspondencia.

78 SEP Velazquez Chávez.

79 "Strand to Chávez," March 12, 1934. AGN Chávez Paul Strand: Correspondencia.

80 "Chávez to Strand," March 16, 1934. AGN Chávez Paul Strand: Correspondencia. 
the filmmakers along nationalistic and perhaps age lines, despite their shared artistic and political convictions.

Tensions can also be noted between the filmmakers and the local population. The professional actors were paid as much as six times more than the villagers, causing occasional protests. There were two small movie houses in Alvarado. The townspeople had seen Hollywood films and thought they were deserving of Hollywood wages. ${ }^{81}$ At one point late in production, a group of local fisherman claimed that the boats being used to film the movie had been abandoned and sought to confiscate them, though that request was denied. ${ }^{82}$ Some moments lend themselves to gentle irony. For example, there is a climactic scene in the film when a corrupt local politician in league with the fish buyer assassinates Miro. At this point, with Miro's sacrifice serving as an incentive to overcome divisions in their ranks, a new hero emerges to lead the workers to unionization and victory. According to Strand, one of the local actors playing the role of Mingo, a foreman on the fishing boat, deeply desired to be the new hero emerging from the ranks. When Strand explained that he was the foreman and thus an inappropriate choice for this role, and then chose a fisherman from another village, Mingo quit and shaved off his distinctive beard in protest. Since he had a key role to play in the film, Stand had to delay shooting his scenes for a month, until his beard grew back. ${ }^{83}$

Other moments held the potential for more severe consequences. The film was highly critical of locally powerful people, and especially politicians, whose corruption and undemocratic tendencies proved to be an enduring problem for the Mexican Revolution. This created a dangerous situation in Alvarado. Much of the film had to be done secretly. The local cast never heard Miro's most radical speeches and thus never understood the full implications of the film they were making. According to Strand "The rest of the cast never heard those speeches. When Miro spoke to the group, he talked innocuously of the need for more and better schools for the children of the state of Veracruz. The real punch lines were all taken in close-ups, away from the crowd." ${ }^{4}$ These political difficulties permeated the making of the film at the local level. Though Strand repeatedly demonstrated his sensitiv-

${ }^{81}$ Michel Mok, "Spare the Rod and Spoil the Actress: She's Just a Simple (Not So Simple) Fishermaid, but she went Garbo Before the Movie Camera." New York Evening Post, May 11 1937. In AGN Chávez Caja Escritos 2: Redes.

${ }^{82}$ Efrén N. Mata to C. Secretario el Ramo," October 23, 1934. SEP Cinematografía.

83 Mok, "Spare the Rod."

84 Ibid. 
ity to nationalist sentiment in Mexico, in the end this proved to be a decisive consideration in the fate of Redes. Many commentators have noted that the film ends abruptly, though the reasons why are more interesting than the "budget considerations" usually cited.

The filmmakers continued on through the summer of 1934 and well into the fall. Cost overruns and production delays continued. These gained the attention of the SEP bureaucracy in a new way due to a series of events beginning in May 1934. On May 9, 1934 Narcisso Bassols resigned his post as director of SEP. He did so in the midst of controversies including church/state conflicts over public and especially sexual education, but also because of conflicts with teachers unions and as a result of chronic infighting and intrigues. ${ }^{85}$ Antonio Castro Leal soon replaced Carlos Chávez as the director of Fine Arts. One result of this change was a review of ongoing projects, including the overbudget and behind schedule film being shot in Alvarado. Antonio Castro Leal chose Augustin Velázquez Chávez to return to Alvarado and write a complete report on the entire production, which he did in July 1934. The result was a mandate to finish production by December 1934 or face an immediate cessation of all funds. ${ }^{86}$ This, however, was just the beginning.

On September 30, 1934 Fidel Murillo published an interview with Augustin Velázquez Chávez in La Opinion, a Spanish language newspaper in Los Angeles, where Velázquez Chávez had been visiting as a representative of SEP. According to Murillo, Mexico was in the final stages of producing a new film. The article claimed, "the production is by Velázquez Chávez, the argument his also, in collaboration with Paul Strand, and the direction under the charge of Emilio Muriel Gómez (sic) and Fred Zimmerman (sic). The music is original by Silvestre Revueltas, performed by the Symphonic Orchestra of Mexico." ${ }^{87}$ Shortly thereafter, Agustin Velázquez Chávez gained control over the entire production. The task of writing the musical score was taken from Carlos Chavez, and given to Carlos Chavez's former student and Agustin Velázquez Chavez's friend, Silvestre Revueltas. Rather than firing Strand, Antonio Castro Leal simply created a new Section of Cinema headed by Velázquez Chávez and gave the latter control over the film's budget and all materials pertaining to the film, including the nega-

${ }^{85}$ Britton, Educación, pp. 112-114.

86 Agustin Velazquez Chávez to C. Jefe del Departamento de Bellas Artes." July 28, 1934. SEP Cinematografia.

${ }^{87}$ Fidel Murillo, "Una cinta del tropico, lista a fin del año: Se titula 'pescados', y está siendo producida por el Sr. Veleazquez Chavez.” La Opinion, Los Angeles, California, September 30, 1934. In AGN Chávez Paul Strand 1930-39. 
tives. In response to a pained and accusatory letter from Carlos Chávez to Strand protesting his removal from writing the music for the film, Strand sent a telegraph on November 4, 1934: "There is plenty of Trickiness and Dishonesty Around As I now see but please Believe I have Never Been Deliberately or Consciously Disloyal to you." 88 It would take several years for these matters to be sorted out. In the short run, however, Strand was given one month to finish filming and then had to leave Mexico.

On February 28, 1935, back in New York City, Strand composed a long summary (thirteen typed pages) of "the facts concerning the history of the filming of "Pescados," the original name of the film ultimately known as Redes, or The Wave in English. Though the letter was addressed to Ignacio García Telles at SEP, it was not possible to locate the original in SEP archives. However, what appears to be a carbon copy of a draft remains in the Carlos Chávez collection at the AGN. Due to marginal notations, it is plausible to believe that Strand and Chávez wrote it together, and that Chávez translated it into Spanish. This source, written in Strand's voice, makes a persuasive case that the young, possibly overly ambitious Augustin Velázquez Chávez inappropriately claimed credit for more of the film than he was responsible for. In fact, Strand uses terms like "deceit," "intrigue," and "destruction" of "a spirit of disinterested cooperation." Strand considered the replacement of Carlos Chávez by Silvestre Revueltas, choreographed largely by Velázquez Chávez, to be especially dishonest. The disillusioned tone of this document is remarkable, as is Strand's claim that after Velázquez Chávez gained control of the budget he could not pay his foreign staff wages or travel expenses. In fact, Rodakiewicz and Zinnemann had to borrow money to get home. Once back in New York, Strand paid several hundred dollars in camera repairs out of his own pocket. ${ }^{89}$

\section{Conclusion: Gateway, Hidalgo}

Gateway, Hidalgo 1933 is the final photograph in Strand's Photograph's of Mexico. An arched stone gateway, with the look and apparent feel of the colonial era, frames a narrow, tall rectangular whitewashed building off in the distance. Clouds, in turn, frame the gateway and the building, and the interplay of light and shadows causes subtle distinctions throughout the photo. In the center, towards the bottom of the passage through the arch, is the doorway of the building. Of course, a gateway can be either an entrance

88 "Strand to Chávez, November 4, 1934. AGN Chávez Paul Strand 1930-39.

89 "Strand and Chávez to Ignacio Garcia Telles," February 28, 1935. 
or an exit depending on how it is used, though in this case it symbolized Strand's departure from Mexico.

We depart from this essay by returning to Redes. Two key moments reveal the complexities of image, meaning and interpretation. Surprisingly, they also demonstrate how even an objective "straight photographer" like Strand could choose to ignore one reality in order to enhance another. In the fishing scene, a joyful harvest supposedly takes place. A simple deconstruction, playful in its betrayal of the filmmaker's craft, reveals that they did not actually catch any fish. The longest production delay occurred because the fish simply did not run that year. Finally, in desperation, Strand, Rodakiewicz, Zinneman, Gómez Muriel and probably Antonio Lara scoured the countryside, purchasing all available fish. According to Strand: "We had to keep the haddocks alive in a tank while we rehearsed the players [. . . ]. It wasn't easy. Lot's of fish gave up the ghost, and the smell was unbearable. When the lads were rehearsed, we put the surviving fish in the nets, which were then presumably hauled up from the gulf."90

At the deeper level of unintended meanings, the fishing scene also reveals the overwhelmingly masculine ambience of this entire venture. Despite multiple revisions of the script, all the filmmakers agreed that this scene must include the "enormous and strong naked chest of a robust fisherman of Alvarado," to reveal something "simple and elemental," though "of great physical force." The irony that the muscular chest and well developed body of professional actor Silvio Hernandez contrasted sharply with many of the overworked and malnourished fisherman of Alvarado seemed lost on the filmmakers, as did a possibly homoerotic aspect in the careful photography of muscular arms, bare chests and strong legs intertwined with fishing nets. ${ }^{92}$ More troubling questions about the gap between image and reality, as well as the film's class and gender politics-and, by extension, those of Strand, SEP and perhaps even the Mexican Revolution itself-are raised in its most powerful scene.

Shortly after the film begins viewers observe the funeral for Miro's young son, who died because his father could not afford basic medical care. This

\footnotetext{
90 Mok, "Spare the Rod."

91 “"Pescados' argumento para una pelicúla que presentan Paul Strand y Agustin Velázquez Chávez," and "Argumento para la filmación de la pelicula "Pescados"-revisión numero siete." AGN Chávez INBA Vol. II, Caja 2 "Filmación Peliculas."

${ }^{2}$ Rudi C. Bleys, Images of Ambiente: Homotextuality and Latin American Art, 1810-Today (London and New York: Continuum, 2000), pp. 57-78.
} 
inability to provide adequately for his son is the event that radicalizes Miro. Accompanied by a haunting musical score, a lengthy procession slowly carries the small casket out of the village to the cemetery. There they provide a traditional burial for the boy, with Miro tossing the first shovels of dirt on the casket before he denounces the injustice of the situation. On the way to the cemetery, the procession passes the child's grieving mother, dressed in black but apparently too distraught to accompany the casket.

In an interview from 1937, after the film had been released in the United States, Strand commented on this woman's role in the film, in frankly brutal terms.

Everybody who has seen the picture [...] has remarked on the talents of that woman. So far as I know, she hasn't any more talent than this ash-tray. It was purely accidental. It so happened that, the morning we shot that sequence, she had been beaten up by her husband. Or, rather, let me put it this way: One fine morning, when she had been beaten up by her husband, we decided to shoot the sequence.

\section{Strand continued}

I couldn't prevent the beating - I assure you it was done in private, behind my back-and there was no harm in taking advantage of it, was there? We needed this sequence. We had rehearsed it innumerable times. The girl, whom I picked merely for her looks, was stolid, cold, unimaginative. But on the morning when she had been smacked, she had just the right expression. She was terribly unhappy, poor thing. She looked as though she had lost her dearest friend. That was just what I wanted and we made the sequence.

After Strand praised her work on the scene, she developed what Strand' termed "a fine case of temperament." She had seen Hollywood films in the two small theaters in Alvarado, and now thought of herself as a star.

After the funeral sequence, she began to balk at her salary. She told me she was the only woman in the cast, the star of the film, and demanded fifty pesos a day. There was no money to pay anybody fifty pesos, or anything like it. We had planned to have a scene at Miro's house after the funeral, but I had to cut it on account of our little Garbo. That's the reason she appears in only one sequence. ${ }^{93}$

${ }^{93}$ Mok, "Spare the Rod." 
Thus, Strand chose not to portray an immediate reality of domestic violence in order to pursue a more distant truth about social justice.

Ironically, given Strand's own stated views, the belief that great art was its own justification appears to be the thread connecting the trick camera of the documentary photographs with the illusions of the film.

Haverford College

JAMES KRIPPNER

Haverford Pennsylvania 